\title{
Corrosion and Leaching Behaviours of Sn-0.7Cu-0.05Ni Lead-Free Solder in 3.5 wt.\% NaCl Solution
}

\author{
Jan-Ervin C. Guerrero, ${ }^{1}$ Drexel H. Camacho ${ }^{D},{ }^{1}$ Omid Mokhtari, ${ }^{2}$ and Hiroshi Nishikawa ${ }^{2}$ \\ ${ }^{1}$ Chemistry Department, De La Salle University, 2401 Taft Avenue, 0922 Manila, Philippines \\ ${ }^{2}$ Joining and Welding Research Institute, Osaka University, 11-1 Mihogaoka, Ibaraki, Osaka 567-0047, Japan
}

Correspondence should be addressed to Drexel H. Camacho; drexel.camacho@dlsu.edu.ph

Received 6 December 2017; Accepted 5 March 2018; Published 2 May 2018

Academic Editor: Arvind Singh

Copyright (C) 2018 Jan-Ervin C. Guerrero et al. This is an open access article distributed under the Creative Commons Attribution License, which permits unrestricted use, distribution, and reproduction in any medium, provided the original work is properly cited.

\begin{abstract}
The corrosion and leaching behaviour of a new ternary $\mathrm{Sn}-0.7 \mathrm{Cu}-0.05 \mathrm{Ni}$ alloy in $3.5 \mathrm{wt} . \% \mathrm{NaCl}$ solution is reported herein. Potentiodynamic polarization measurements show that $\mathrm{Sn}-0.7 \mathrm{Cu}-0.05 \mathrm{Ni}$ has the highest corrosion rate. Results of the 30 -day $\mathrm{Sn}$ leaching measurement show that $\mathrm{Sn}-\mathrm{Cu}-\mathrm{Ni}$ joint has slight decrease attributed to the formation of thin passivation film after 15 days. The leaching amounts of Sn are observed to be higher in solder joint than in solder alloy due to the galvanic corrosion happening on the surface. EDS and XRD results of the corroded surface confirm that the corroded product is made up of oxides of tin.
\end{abstract}

\section{Introduction}

Solder, a fusible metal alloy used to join metal pieces, is a staple material in the electronics industry. It functions as an adhesive or joining material to provide electrical continuity between the active silicon die, the substrate, and the printed wiring boards [1]. Solder alloys made up of tin and lead (Sn$\mathrm{Pb})$ predominate the manufacturing and electronics industries for years. However, due to the bad effects of lead and its compounds to human health and the environment [2], its use has been widely limited if not banned.

Global lead-free regulations started with the US banning lead $(\mathrm{Pb})$ in gasoline additives, plumbing, and construction [3]. Japan pioneered the use of lead-free solders in the electronics industry and the European Union (EU) passed the restriction of the use of certain hazardous substances (ROHS) in electrical and electronic equipment banning the use of lead, mercury, and cadmium, among others [4]. Thus, there was a critical necessity to look for alternatives to $\mathrm{Pb}$ solders for the electronics industry. For solders to be a good environmentally benign substitute to $\mathrm{Pb}$, it should be costeffective and should mimic the properties of $\mathrm{Pb}$, that is, low melting temperature (around $183^{\circ} \mathrm{C}$ ), good mechanical, thermal, and electrical properties. Almost every lead-free solder in the market is Sn-based solders such as $\mathrm{Sn}-\mathrm{Ag}-\mathrm{Cu}$ and $\mathrm{Sn}$ $\mathrm{Cu}$ [1]. At present, there is no common standard for lead-free electronic products since each country or region has its own recommended lead-free solders. In the US, the National Electronic Manufacturing Initiative, Inc., (NEMI) recommends Sn-3.9Ag-0.6Cu as the lead-free solder. Japan, through the Japan Electronic and Information Technology Association (JEITA), recommends the use of $\mathrm{Sn}-3.0 \mathrm{Ag}-0.5 \mathrm{Cu}$ solder alloy, while the European Consortium recommends Sn-3.8Ag$0.5 \mathrm{Cu}$ as the lead-free solder. Overall, the most common type of lead-free solder (LFS) used worldwide is the alloy made up of $\mathrm{Sn}-\mathrm{Ag}$-Cu. Alternative $\mathrm{Pb}$-free solder systems such as $\mathrm{Sn}$ $\mathrm{Ag}, \mathrm{Sn}-\mathrm{Bi}, \mathrm{Sn}-\mathrm{Zn}$, and $\mathrm{Sn}-\mathrm{Cu}$ have been developed $[1,5,6]$ but uncertainties in their integrity and reliability limited their use in consumer products [7]. New types of lead-free solders are being used by some companies in Japan; Panasonic and Hitachi use Sn-Ag-Bi, Sharp uses $\mathrm{Sn}-\mathrm{Bi}$, and Sony uses Sn$\mathrm{Ag}-\mathrm{Bi}-\mathrm{Cu}$ and $\mathrm{Sn}-\mathrm{Ag}-\mathrm{Bi}-\mathrm{Ge}$ solder alloys in their products $[3,4]$. New lead-free solder alloys are being studied [8-10] and reliable solders for general and specific applications are still highly sought.

The ternary alloy $\mathrm{Sn}-0.7 \mathrm{Cu}-0.05 \mathrm{Ni}$ has been shown to be a potential $\mathrm{Pb}$-free solder [11] where the wettability of the alloy was shown to be comparable with some other lead-free 


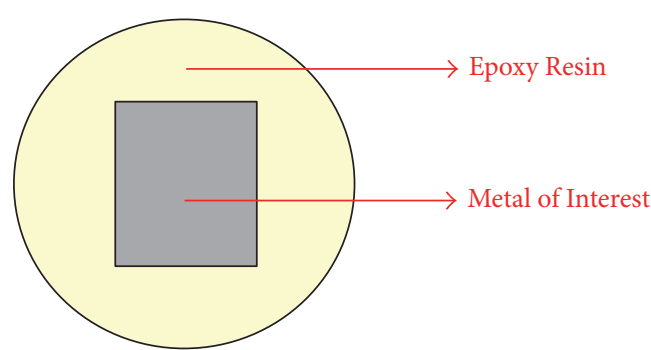

(a)

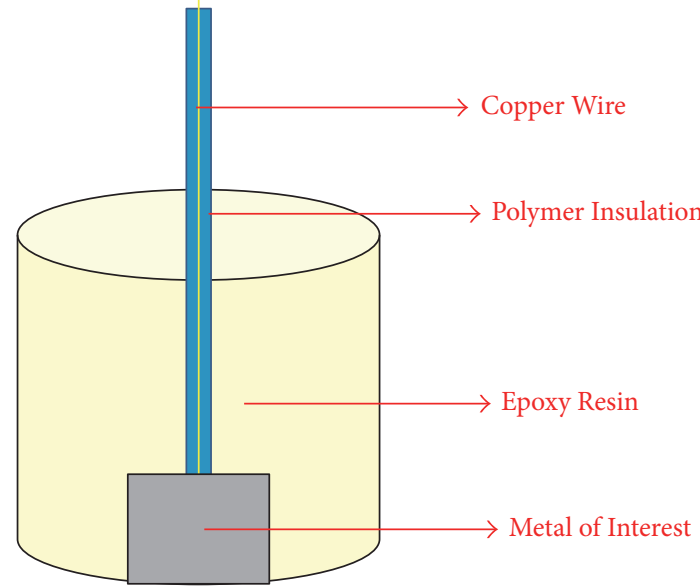

(b)

FIGURE 1: Schematic diagram of the working electrode. (a) Bottom view; (b) side view.

solders [12]. The low experimental wetting angle is a consequence of the addition of $\mathrm{Ni}$ in $\mathrm{Sn}-0.7 \% \mathrm{wt}$. Cu. Increasing the amount of $\mathrm{Ni}$ also decreases the void percentage and $\mathrm{Cu}_{3} \mathrm{Sn}$ growth in $\mathrm{Sn}-\mathrm{Cu}$ solder alloy [13]. The tensile properties and wettability in solder joints with $\mathrm{Cu}$ also improved as a result of adding $0.05 \mathrm{wt} . \% \mathrm{Ni}$ [14]. The addition of $0.05 \mathrm{wt} . \% \mathrm{Ni}$ to Sn$0.7 \mathrm{Cu}$ solder was shown to effectively reduce the formation of intermetallic compound (IMC) layer at the interface during the reflow process and for inhibiting the growth of IMC during the aging process [15].

To study further the potential of $\mathrm{Sn}-0.7 \mathrm{Cu} 0.05 \mathrm{Ni}$ solder alloy, there is a need to assess its corrosion behaviour as it is an important factor to consider in formulating new solder materials [16]. The presence of moisture and corrosive salts/ions triggers the corrosion activity of these solder metals affecting the form, fit, and function of the electronic device $[17,18]$. Corrosion behaviours of lead-free solders are mainly studied using sodium chloride $(\mathrm{NaCl})$ electrolyte to simulate the seawater condition using different types of lead-free solders [19-24]. Li et al. [20] reported that lead-free solders such as $\mathrm{Sn}-3.5 \mathrm{Ag}, \mathrm{Sn}-0.7 \mathrm{Cu}$, and $\mathrm{Sn}-3.8 \mathrm{Ag}-0.7 \mathrm{Cu}$ exhibit better corrosion resistance than $\mathrm{Sn}-\mathrm{Pb}$ solder in $3.5 \mathrm{wt} . \% \mathrm{NaCl}$ solution, where $\mathrm{Sn}-3.5 \mathrm{Ag}$ solder was found to be the most resistant among them. Lead-free solder exhibits better corrosion resistant because it exhibits lower passivation current density, lower corrosion current density after the breakdown of the passivation film, and a more stable passivation film on the surface compared to $\mathrm{Sn}-\mathrm{Pb}$ solder. By investigating the corrosion behaviours of new lead-free solders, the fatigue life of the material can be predicted. A cursory survey of the literature reveals zero investigation on the corrosion behaviour of the new ternary $\mathrm{Sn}-0.7 \mathrm{Cu}-0.05 \mathrm{Ni}$ alloy. The goal of the present study is to investigate the corrosion resistance of $\mathrm{Sn}-0.7 \mathrm{Cu}-0.05 \mathrm{Ni}$ as compared to commercially used solder alloys and metal and study the leaching behaviour of tin in the alloys and in their corresponding joints in $3.5 \mathrm{wt} \% \mathrm{NaCl}$ solution.

\section{Materials and Methods}

\subsection{Materials}

2.1.1. Preparation of Working Electrode. The compositions of the solder alloys used in the study are $\mathrm{Sn}-0.7 \mathrm{wt} . \% \mathrm{Cu}-$ 0.05 wt.\% Ni, Sn-3.0 wt.\% Ag-0.5 wt.\% Cu and Sn-0.8 wt.\% $\mathrm{Cu}, 60 \mathrm{wt} . \% \mathrm{Sn}-40 \mathrm{wt} . \% \mathrm{~Pb}$, and pure Sn metal. The alloys were cut using low-speed cut-off saw into square blocks (approximate dimension of $0.5 \times 0.5 \times 0.5 \mathrm{~cm}$ ). Each metal piece was attached to an insulated $\mathrm{Cu}$ wire by hand soldering using the same metal alloy to provide electrical connections and then cold-mounted using epoxy resin as shown in Figure 1. The specimens were ground using $\mathrm{SiC}$ paper/sand paper up to 1200 grit, rinsed with distilled water, and cleaned in an ultrasonic cleaner for 2 mins. The surface area exposed to the test solution was $0.5 \pm 0.2 \mathrm{~cm}^{2}$.

2.1.2. Preparation of Solder Alloy and Solder Joint for Leaching Measurement. Solder joints were prepared by joining a previously acid-cleaned $\left(\mathrm{HNO}_{3} / \mathrm{MeOH}\right)$ copper plate $(5 \times 10$ $\times 2 \mathrm{~mm}$ ) with similarly sized lead-free solder plate using a solder paste. The coupled metals were heated on a hot plate at $230^{\circ} \mathrm{C}$ until the solders stuck on the $\mathrm{Cu}$ plate. For leaching experiments, the samples were prepared as shown in Figure 2.

2.1.3. Preparation of Solution. The corrosion test was carried out at room temperature in air-saturated aqueous solution of $3.5 \mathrm{wt} . \% \mathrm{NaCl}$ prepared by dissolving 17.5 grams of analytical grade $\mathrm{NaCl}$ dissolved in deionized water to make a $500 \mathrm{~mL}$ solution.

\subsection{Methods}

2.2.1. Potentiodynamic Polarization Method-Tafel Plot. Electrochemical measurements were carried out in a single compartment cell using a standard three-electrode setup: $\mathrm{Ag} / \mathrm{AgCl}(3 \mathrm{M} \mathrm{KCl})$ as a reference electrode, a platinum sheet 


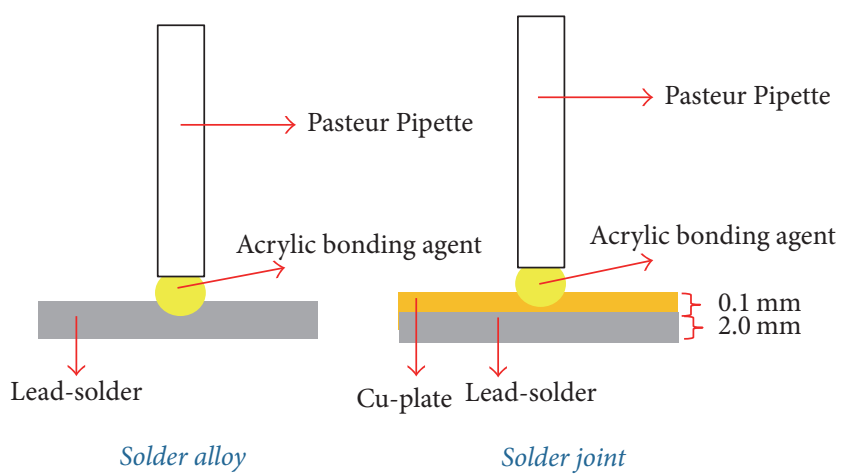

Figure 2: Preparation of samples for leaching measurements.

$\left(0.64 \mathrm{~cm}^{2}\right)$ as a counter electrode, and the lead-free solders as the working electrode. All the measurements were done under $\mathrm{N}_{2}$ conditions. Metrohm Autolab PGSTAT $128 \mathrm{~N}$ was used as an electrochemical interface to control and record the potential. The samples were immersed in $250 \mathrm{~mL}$ corrosive medium inside the cell at room temperature for $180 \mathrm{~s}$ to attain a steady-state potential or open circuit potential (OCP). Potentiodynamic polarization curves were determined at -1500 to $500 \mathrm{mV}$ range distinctive for the lead-free solder used on the study at an ASTM scan rate of $1.00 \mathrm{mV} / \mathrm{s}$; step potential is at $0.45 \mathrm{mV}$ and is presented in the form of typical polarization curves $\log I$ versus voltage. From the Tafel plot, the corrosion current $\left(I_{\mathrm{CORR}}\right)$, corrosion potential $\left(E_{\mathrm{CORR}}\right)$, polarization resistance $\left(R_{p}\right)$, and corrosion rate $(\mathrm{CR})$ of the metal alloys were calculated using the corrosion rate, Tafel slope method (Autolab application note COR02).

2.2.2. Leaching Measurements. For the leaching/dissolution measurement, the method by Cheng et al. [25] was adopted with slight modification. Small test cells containing $15 \mathrm{~mL}$ of test solutions were placed in a temperature-controlled oil bath at $45 \pm 3^{\circ} \mathrm{C}$. Every 3 days, oxygen was injected into the test solutions by gas flowmeter with a flow rate of $46 \mathrm{~mL} / \mathrm{min}$ for $5 \mathrm{mins}$ to keep the solution under low saturation of oxygen. Two $\mathrm{mL}$ of fresh test solutions was added to the test cell every 7 days or when the solution is reduced to keep the solution at $15 \mathrm{~mL}$. The testing periods were done for 7, 15, and 30 days. After immersion for the subscribed period, $15 \mathrm{~mL}$ was taken and diluted into a $25 \mathrm{~mL}$ volumetric flask with deionized water. If there exists some precipitation in the test solution, sodium phosphate solution was used to dissolve the precipitates. The concentration of Sn in the diluted solution was analyzed using Atomic Absorption Spectrophotometer (Shimadzu AA-6300 Atomic Absorption Spectrophotometer) and the leaching amount per surface area of each element in the solders and their joints were calculated.

2.2.3. Surface Morphology and Elemental Analysis. The corroded surfaces of the samples were investigated using fieldemission scanning electron microscopies (FESEM) (JEOL JSM-5310) and SEM (JEOL JSM-6500F) both equipped

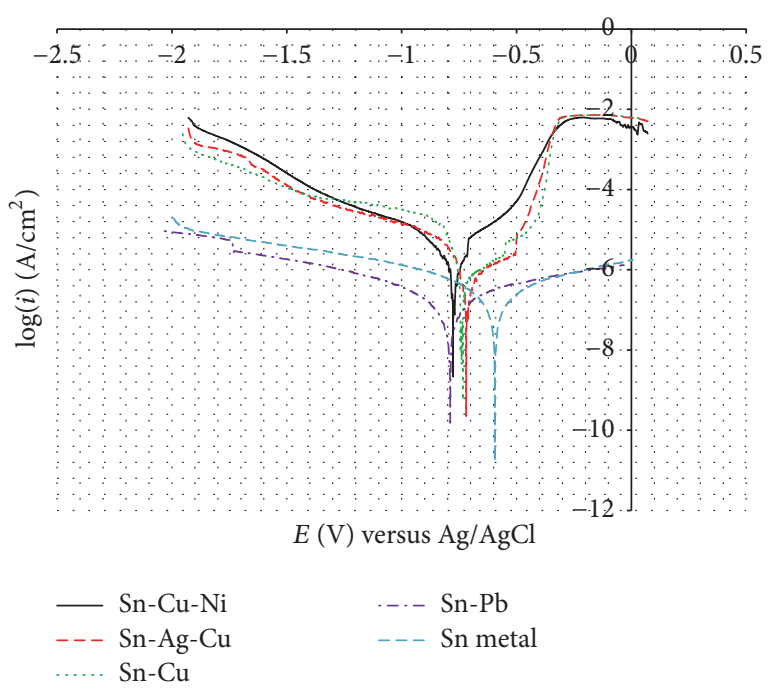

FIgURE 3: Potentiodynamic polarization curves of $\mathrm{Sn}$ and solder alloys in $3.5 \mathrm{wt} . \% \mathrm{NaCl}$ solution under $\mathrm{N}_{2}$ atmosphere. Scan range: from -1500 to $500 \mathrm{mV}$; scan rate: $1.00 \mathrm{mV} / \mathrm{s}$; step potential: $0.45 \mathrm{mV}$.

with an energy dispersive X-ray spectroscopy (EDS). Xray diffraction (XRD) measurements were performed with a diffractometer (Rigaku Ultima IV) using $\mathrm{Cu}-\mathrm{K} \alpha$ radiation $(\lambda$ $=1.5405 \AA$ ) at an accelerating voltage of $40 \mathrm{kV}$. The diffracted beam was scanned in steps of $0.02^{\circ}$ across a $2 \theta$ range of $20-90^{\circ}$.

\section{Results and Discussion}

3.1. Potentiodynamic Polarization Method-Tafel Plot. The Sn0.7CuNi0.05 (referred to herein as $\mathrm{Sn}-\mathrm{Cu}-\mathrm{Ni}$ ) in $3.5 \mathrm{wt} . \%$ $\mathrm{NaCl}$ solution showed a Tafel plot positioned at $\left(E_{\text {corr }}\right)$ $-0.78 \mathrm{mV}$ versus $\mathrm{Ag} / \mathrm{AgCl}$ (Figure 3 ). As compared to Sn3.0Ag-05Cu (referred to herein as $\mathrm{Sn}-\mathrm{Ag}-\mathrm{Cu}$ ) and $\mathrm{Sn}-0.8 \mathrm{Cu}$ (referred to herein as $\mathrm{Sn}-\mathrm{Cu}$ ) alloys, there is an observed shift of corrosion potential $E_{\text {corr }}$ of lead-free solders to a less negative value following the sequence $\mathrm{Sn}-\mathrm{Cu}-\mathrm{Ni}<\mathrm{Sn}$ $\mathrm{Cu}<\mathrm{Sn}-\mathrm{Ag}-\mathrm{Cu}$. During the anodic polarization process, a stable passivation film is formed on the surface of the metal alloys (vide infra). This passivation film determines the corrosion behaviour of the solder in the given media. The shift to a less negative potential signifies a formation of a more stable passivation film [26], which protects the solders and increases their corrosion resistance. The polarization resistance $\left(R_{p}\right)$ data (Table 1$)$ showed that $\mathrm{Sn}-\mathrm{Pb}$ solder has the highest $R_{p}(805.250 \mathrm{~K} \Omega)$ and lowest corrosion rate $(0.1949$ $\times 10^{-2} \mathrm{~mm} / \mathrm{yr}$ ) compared to the lead-free solders. Between the three lead-free solder alloys, $\mathrm{Sn}-\mathrm{Cu}-\mathrm{Ni}$ showed the highest corrosion rate and $\mathrm{Sn}-\mathrm{Ag}-\mathrm{Cu}$ showed the lowest corrosion rate in $3.5 \mathrm{wt} . \% \mathrm{NaCl}$ solution.

3.1.1. Microstructure Characterization of the Lead-Free Solders. The microstructure of solders before potentiodynamic polarization (Figure 4(a)) is a smooth surface showing the polishing lines and EDS analysis confirms the elemental 
TABLE 1: Summary of corrosion parameters of metal alloys in $3.5 \mathrm{wt} . \% \mathrm{NaCl}$ solution.

\begin{tabular}{lcccc}
\hline Sample & $\begin{array}{c}E_{\text {corr }} \\
(\mathrm{V}) \text { versus Ag/AgCl }\end{array}$ & $\begin{array}{c}I_{\text {corr }} \\
\left(\mu \mathrm{A} / \mathrm{cm}^{2}\right)\end{array}$ & $\begin{array}{c}R_{p} \\
(\mathrm{k} \Omega)\end{array}$ & $\begin{array}{c}\mathrm{CR} \\
(\mathrm{mm} / \mathrm{yr}) \times 10^{-2}\end{array}$ \\
\hline $\mathrm{Sn}-\mathrm{Cu}-\mathrm{Ni}$ & -0.78 & 8.98 & 14.94 & 4.87 \\
$\mathrm{Sn}-\mathrm{Ag}-\mathrm{Cu}$ & -0.73 & 3.06 & 43.86 & 1.71 \\
$\mathrm{Sn}-\mathrm{Cu}$ & -0.75 & 3.91 & 28.26 & 2.07 \\
$\mathrm{Sn}-\mathrm{Pb}$ & -0.79 & 0.39 & 805.25 & 0.19 \\
$\mathrm{Sn}$ & -0.59 & 0.55 & 406.02 & 0.23 \\
\hline
\end{tabular}

$E_{\text {corr }}$ : corrosion potential, $I_{\text {corr }}$ : corrosion current density, $R_{p}$ : polarization resistance, and CR: corrosion rate.

TABLE 2: Surface element concentration of different solders before potentiodynamic polarization in $3.5 \mathrm{wt}$. $\mathrm{NaCl}$ solution.

\begin{tabular}{lccccc}
\hline & & \multicolumn{3}{c}{ Surface element composition (atom\%) } & $\mathrm{Cu}$ \\
\hline $\mathrm{Sn}-\mathrm{Cu}-\mathrm{Ni}$ & $\mathrm{Ag}$ & - & $\mathrm{Cu}$ & 0.14 \\
$\mathrm{Sn}-\mathrm{Ag}-\mathrm{Cu}$ & 98.59 & 2.74 & 0.52 & - & - \\
$\mathrm{Sn}-\mathrm{Cu}$ & 96.74 & - & 1.38 & - & - \\
$\mathrm{Sn}-\mathrm{Pb}$ & 98.97 & - & - & - & - \\
$\mathrm{Sn}$ & 59.03 & - & - & - \\
\hline
\end{tabular}
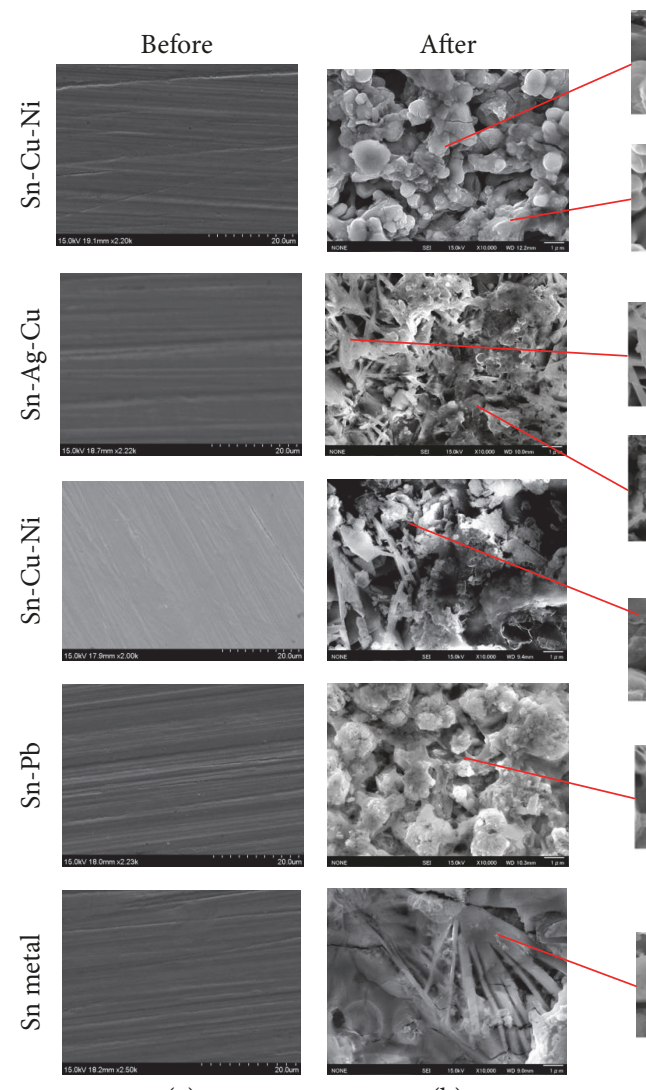

(a) (b)
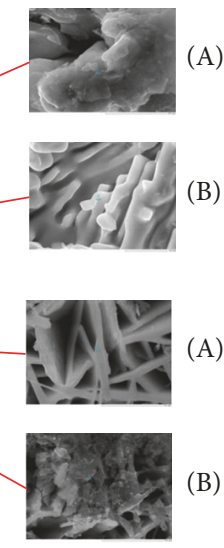

(B)
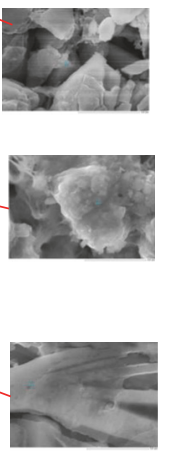

(c)
FIGURE 4: The microstructure of the metal surfaces on different solders before (a), after (b), and distinct morphologies on specified points (c) after potentiodynamic polarization tests in $3.5 \mathrm{wt} . \% \mathrm{NaCl}$ solution. composition of each solder (Table 2). After potentiodynamic polarization in $3.5 \mathrm{wt} . \% \mathrm{NaCl}$ solution (Figure 4(b)), the microstructure of corroded $\mathrm{Sn}-\mathrm{Cu}-\mathrm{Ni}$ alloy had a porous flake-like surface while the $\mathrm{Sn}-\mathrm{Ag}-\mathrm{Cu}$ and $\mathrm{Sn}-\mathrm{Cu}$ solders showed fibrous network oriented randomly on the surface in agreement with the observations of $\mathrm{Li}$ et al., [20]. Notable is the flake-like microstructures in $\mathrm{Sn}-\mathrm{Cu}-\mathrm{Ni}$, which is similar in some respect to the $\mathrm{Sn}-\mathrm{Pb}$ alloy. The EDS analysis on the surface of the corroded samples on each specified point was determined (Figure 4(c) and Table 3) and revealed the presence of $\mathrm{Sn}, \mathrm{O}$, and $\mathrm{Cl}$ indicating that the corrosion products are composed of the oxides and chlorides of tin. In conventional electrochemical reaction, $\mathrm{Sn}$ acts as an anode and reacts with $\mathrm{Cl}^{-}$from the medium to form $\mathrm{SnCl}_{2}$, which results in pitting and severed dissolution of $\mathrm{Sn}$ [27].

The cross-section of the metals after potentiodynamic polarization (Figure 5) showed visible corrosion layers distinct from the bulk metal. EDS analysis of the cross-section area (Table 4) for both lead and lead-free solders showed the top layer having similar corrosion products composed of $\mathrm{Sn}$-rich and $\mathrm{O}$-rich areas with $<1 \% \mathrm{Cl}$. The $\mathrm{Sn}-\mathrm{Pb}$ solder showed an outer layer rich in $\mathrm{O}$ while the inner layer was rich in Sn. The formation of oxides on the surface of the $\mathrm{Sn}-\mathrm{Pb}$ solder indicates the presence of a stable passivation film that protects the metal from corroding. This explains why $\mathrm{Sn}-\mathrm{Pb}$ solder has a better corrosion resistance than lead-free solders. In the case of the lead-free solders, since they have a different composition than $\mathrm{Sn}-\mathrm{Pb}$, the thin layer of oxides that formed on the surface of the alloy is not enough to protect the metal from the electrochemical process. 
TABLE 3: Surface element concentration of different solders after potentiodynamic polarization in $3.5 \mathrm{wt} . \% \mathrm{NaCl}$ solution on specific points as indicated in Figure 4(c).

\begin{tabular}{|c|c|c|c|c|c|c|c|}
\hline & \multicolumn{7}{|c|}{ Surface element concentration (atom\%) } \\
\hline & Sn & Ag & $\mathrm{Cu}$ & $\mathrm{Pb}$ & $\mathrm{Ni}$ & $\mathrm{Cl}$ & $\mathrm{O}$ \\
\hline $\mathrm{Sn}-\mathrm{Cu}-\mathrm{Ni}(\mathrm{A})$ & 20.40 & - & 1.90 & - & - & 3.50 & 74.20 \\
\hline $\mathrm{Sn}-\mathrm{Cu}-\mathrm{Ni}(\mathrm{B})$ & 56.70 & - & 0.80 & - & - & 0.20 & 42.30 \\
\hline $\mathrm{Sn}-\mathrm{Ag}-\mathrm{Cu}(\mathrm{A})$ & 23.60 & - & - & - & - & 8.70 & 67.70 \\
\hline $\mathrm{Sn}-\mathrm{Ag}-\mathrm{Cu}(\mathrm{B})$ & 32.30 & - & 0.20 & - & - & 12.10 & 55.40 \\
\hline $\mathrm{Sn}-\mathrm{Cu}$ & 20.50 & - & 0.10 & - & - & 10.70 & 68.70 \\
\hline $\mathrm{Sn}-\mathrm{Pb}$ & 28.40 & - & - & - & - & 0.60 & 71.00 \\
\hline Sn & 29.90 & - & - & - & - & 15.00 & 55.10 \\
\hline
\end{tabular}

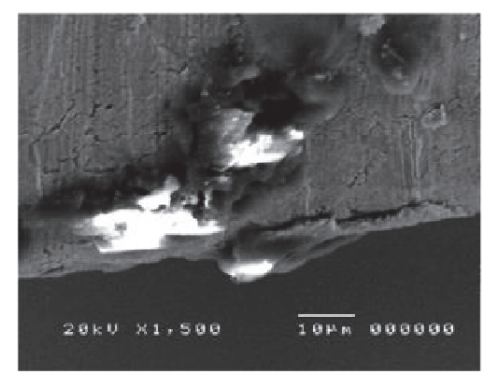

(a)

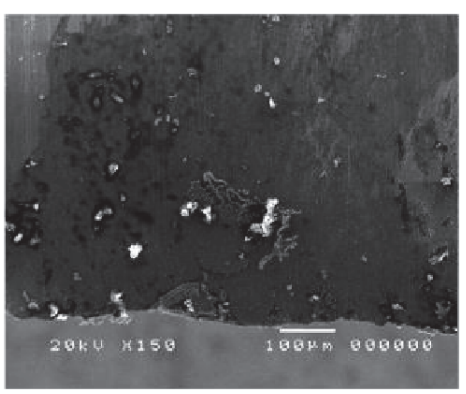

(c)

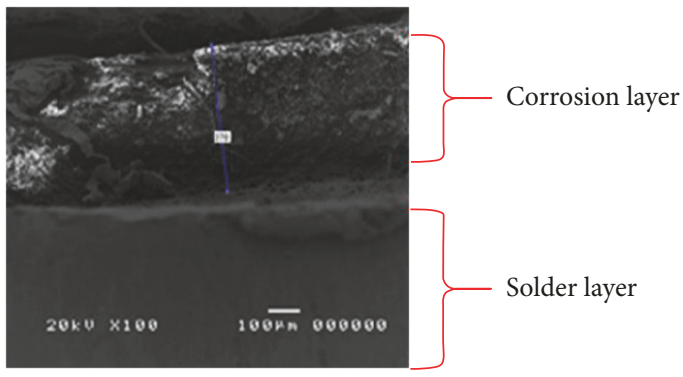

(b)

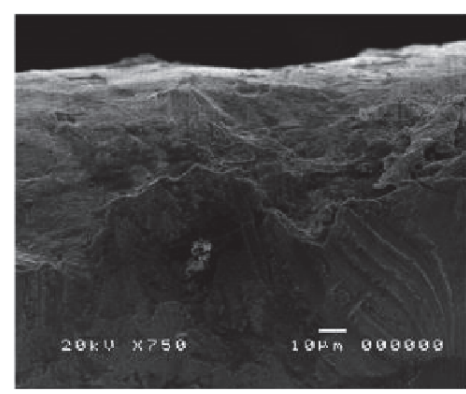

(d)

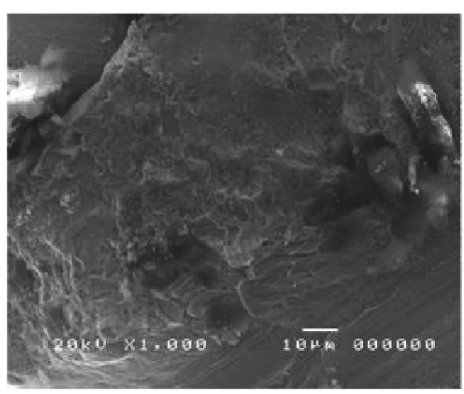

(e)

Figure 5: Cross-section image of the solders after potentiodynamic polarization test in 3.5 wt.\% NaCl solution. (a) Sn; (b) Sn-Pb; (c) Sn-Ag$\mathrm{Cu}$; (d) Sn-Cu-Ni; (e) Sn-Cu.

3.1.2. Phase Composition Analysis of Corrosion Product on the Surface of the Solder Sample. The XRD diffractograms of corrosion products (Figure 6) showed corresponding XRD peaks attributed to tin oxides $\left(\mathrm{SnO}\right.$ and $\left.\mathrm{SnO}_{2}\right)$ and some chlorides. When compared with the XRD results of Yan and Xian [28] peaks for tin hydroxide $\left(\mathrm{Sn}\left(\mathrm{OH}_{2}\right)\right)$ were also observed particularly for $\mathrm{Sn}-\mathrm{Pb}$ and $\mathrm{Sn}$ metal [25]. These oxides effectively protect the metal. The oxides, however, were not visibly detected in $\mathrm{Pb}$-free solders indicating nil or minimal formation of the passivation layer.

During potentiodynamic polarization measurements, the reduction of oxygen in the neutral aqueous solution (1) initially occurs [20]

$$
4 \mathrm{e}^{-}+\mathrm{O}_{2}+2 \mathrm{H}_{2} \mathrm{O} \longrightarrow 4 \mathrm{OH}^{-} .
$$

Once the current reaches $10 \mathrm{~mA} / \mathrm{cm}^{2}$, bubbles were observed from the solution caused by the evolution of hydrogen from the cathode.

$$
2 \mathrm{H}_{2} \mathrm{O}+2 \mathrm{e}^{-} \longrightarrow \mathrm{H}_{2}+2 \mathrm{OH}^{-} \text {. }
$$

The following plausible anodic reactions would occur $[17,19]$ :

$$
\begin{aligned}
\mathrm{Sn} & \longrightarrow \mathrm{Sn}^{2+}+2 \mathrm{e}^{-} \\
\mathrm{Sn}^{2+} & \longrightarrow \mathrm{Sn}^{4+}+2 \mathrm{e}^{-} \\
\mathrm{Sn}+2 \mathrm{OH}^{-}-2 \mathrm{e}^{-} & \longrightarrow \mathrm{Sn}(\mathrm{OH})_{2} \\
\mathrm{Sn}+2 \mathrm{OH}^{-}-2 \mathrm{e}^{-} & \longrightarrow \mathrm{SnO}+\mathrm{H}_{2} \mathrm{O} \\
2 \mathrm{Sn}+\mathrm{O}_{2}+6 \mathrm{H}_{2} \mathrm{O} & \longrightarrow \mathrm{Sn}(\mathrm{OH})_{2} \\
\mathrm{Sn}(\mathrm{OH})_{2}+2 \mathrm{OH}^{-}-2 \mathrm{e}^{-} & \longrightarrow \mathrm{Sn}(\mathrm{OH})_{4} \\
2 \mathrm{Sn}^{2+}+6 \mathrm{H}_{2} \mathrm{O}+\mathrm{O}_{2} & \longrightarrow 2 \mathrm{Sn}(\mathrm{OH})_{4}+4 \mathrm{H}^{+}
\end{aligned}
$$

Formation of tin oxides is thermodynamically favourable thus tin hydroxides can dehydrate easily to form $\mathrm{SnO}$ and $\mathrm{SnO}_{2}[25,29]$. Although not detected in XRD due to its trace concentration relative to $\mathrm{Sn}$, the potential corrosion products 
TABle 4: Cross-section element concentration of different solders after Potentiodynamic polarization tests in $3.5 \mathrm{wt} . \% \mathrm{NaCl}$ solution.

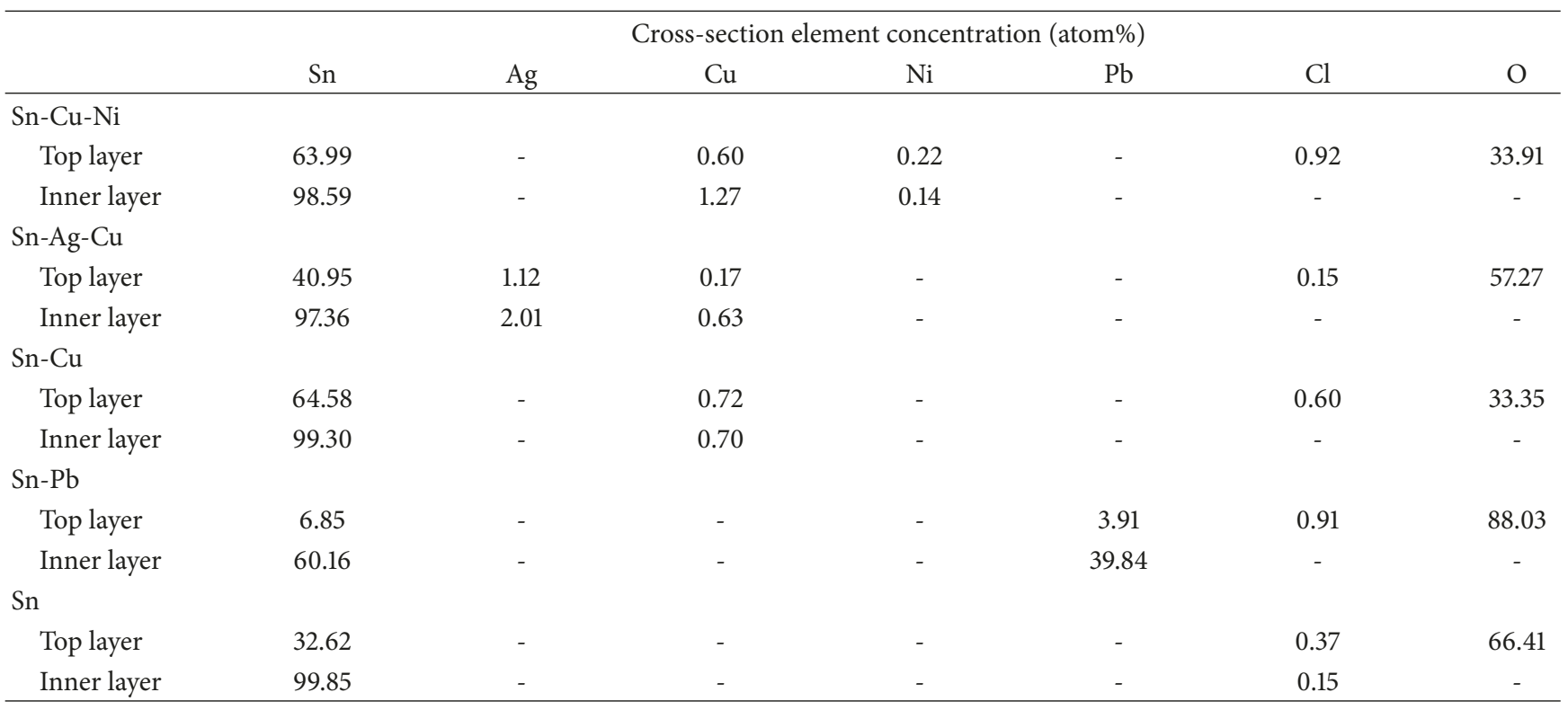
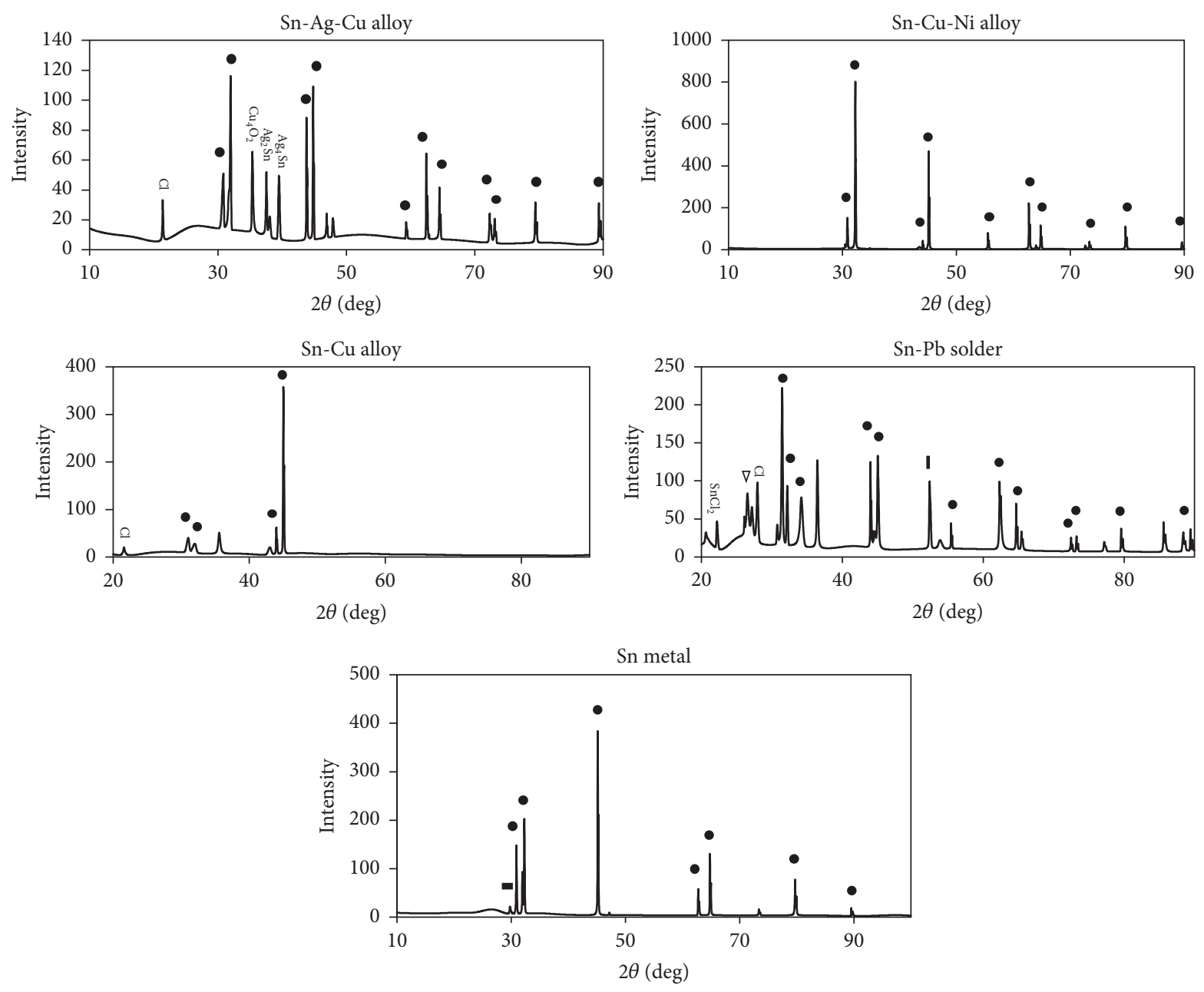

$$
\begin{aligned}
& \text { - } \mathrm{Sn} \\
& \text { - } \mathrm{SnO} \\
& -\mathrm{SnO}_{2}
\end{aligned}
$$

FIGURE 6: XRD patterns of surface product on different solder material after potentiodynamic polarization test. 
of copper and nickel are metal chlorides. Corrosion of copper is dependent on the presence of chloride ions either through direct formation of cupric chloride

$$
\begin{aligned}
\mathrm{Cu} & \longleftrightarrow \mathrm{Cu}^{+}+\mathrm{e}^{-} \\
\mathrm{Cu}^{+}+2 \mathrm{Cl}^{-} & \longleftrightarrow \mathrm{CuCl}_{2}^{-}
\end{aligned}
$$

or through the electro-dissolution of copper [30]

$$
\begin{gathered}
\mathrm{Cu}+\mathrm{Cl}^{-} \longleftrightarrow \mathrm{CuCl}+\mathrm{e}^{-} \\
\mathrm{CuCl}+\mathrm{Cl}^{-} \longleftrightarrow \mathrm{CuCl}_{2}^{-} .
\end{gathered}
$$

The anodic polarization of copper alloys in $\mathrm{NaCl}$ solution lowers the fracture stresses as measured in slow strain experiments making copper alloys under cyclic stresses to have lower service lives in chloride solutions [31]. Thus, chlorides penetrate into the material crevices allowing for corrosion of susceptible atoms such as copper to occur. For nickel corrosion, the initial step is nickel hydration to facilitate dissolution and this can occur when water transport into the material is enhanced. The transport of water is dependent on chloride environment. This was observed when we compared the potentiodynamic polarization of $\mathrm{Sn}-\mathrm{Cu}-\mathrm{Ni}$ alloy in neutral chloride-containing medium $\left(E_{\text {corr }}=-0.776 \mathrm{~V}\right.$ versus $\left.\mathrm{Ag} / \mathrm{AgCl}, I_{\text {corr }}=8.982 \mu \mathrm{A} / \mathrm{cm}^{2}\right)$ and in acidic chloride-free electrolyte $\left(0.1 \mathrm{M} \mathrm{HNO}_{3} ; E_{\text {corr }}=-0.356 \mathrm{~V}\right.$ versus $\mathrm{Ag} / \mathrm{AgCl}$, $\left.I_{\text {corr }}=4.34 \mu \mathrm{A} / \mathrm{cm}^{2}\right)$. A sudden shift of corrosion potential to a less negative value is observed attributed to the formation of the passivation film. The absence of chloride in $\mathrm{HNO}_{3}$ medium promotes barrier creation preventing hydration and corrosion to occur. This suggests that $\mathrm{Sn}-\mathrm{Cu}-\mathrm{Ni}$ alloy has high corrosion resistance in an acidic chloride-free environment. Chlorides even in small amounts can break the protective films initiating the occurrence of corrosion.

3.2. Soldering Properties and Leaching Measurements. During the preparation of the solder joints with copper substrates, a better surface finish of the joints was observed when $\mathrm{Sn}-\mathrm{Cu}-$ $\mathrm{Ni}$ solder was used compared to $\mathrm{Sn}-\mathrm{Cu}$ alloys. The design of adding $\mathrm{Ni}$ to common $\mathrm{Sn}-\mathrm{Cu}$ alloy improved the soldering property [32]. These observations were consistent with the unique morphology of the intermetallic compound (IMC) layer reported by Harcuba et al. [33]. The IMC was described as noncompact islands of solder entrapped in the IMC phase and that the IMC layer contains more $\mathrm{Ni}$ than the solder. Nickel addition promoted the significant acceleration of the growth kinetics of the IMC layer.

The solder joints and the raw $\mathrm{Pb}$-free solder alloys were subjected to corrosive media immersion to determine the leaching behaviour (Figure 7). The amount of Sn leached correlates with the corrosion rate of the alloys [25, 29, 34]. Since the results of potentiodynamic polarization test showed that all of the three $\mathrm{Pb}$-free solders had higher corrosion rate than the $\mathrm{Sn}-\mathrm{Pb}$ solder and $\mathrm{Sn}$ metal, leaching amounts of Sn were done only for the $\mathrm{Pb}$-free solders. The leaching amounts of $\mathrm{Sn}$ after immersion in $3.5 \mathrm{wt}$.\% $\mathrm{NaCl}$ solution after 30 days are observed to be greater for solder joints compared to its corresponding alloy. Sn-Ag-Cu alloy had the highest leaching

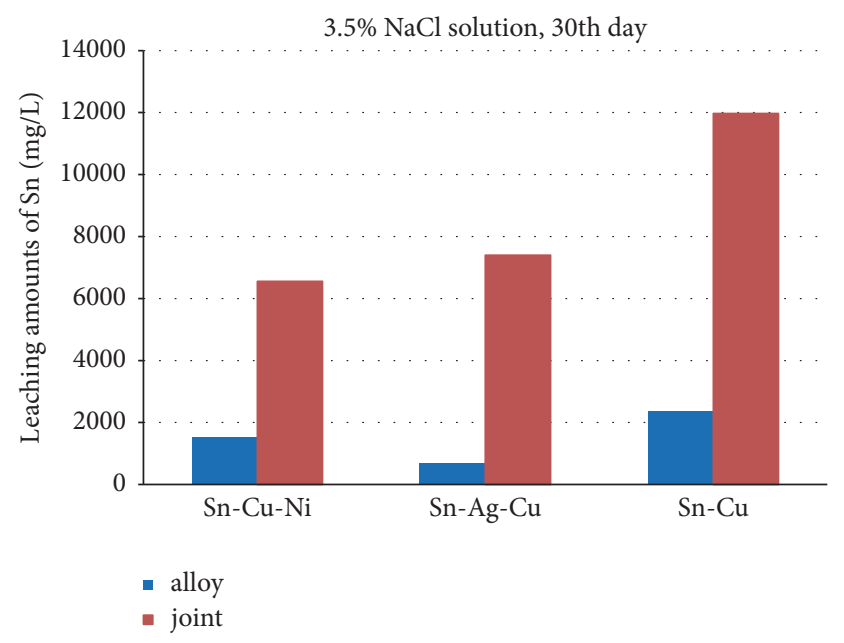

Figure 7: Atomic Absorption Spectroscopy (AAS) results on Tin $(\mathrm{Sn})$ leaching from lead-free solder alloy and joint after 30 days.

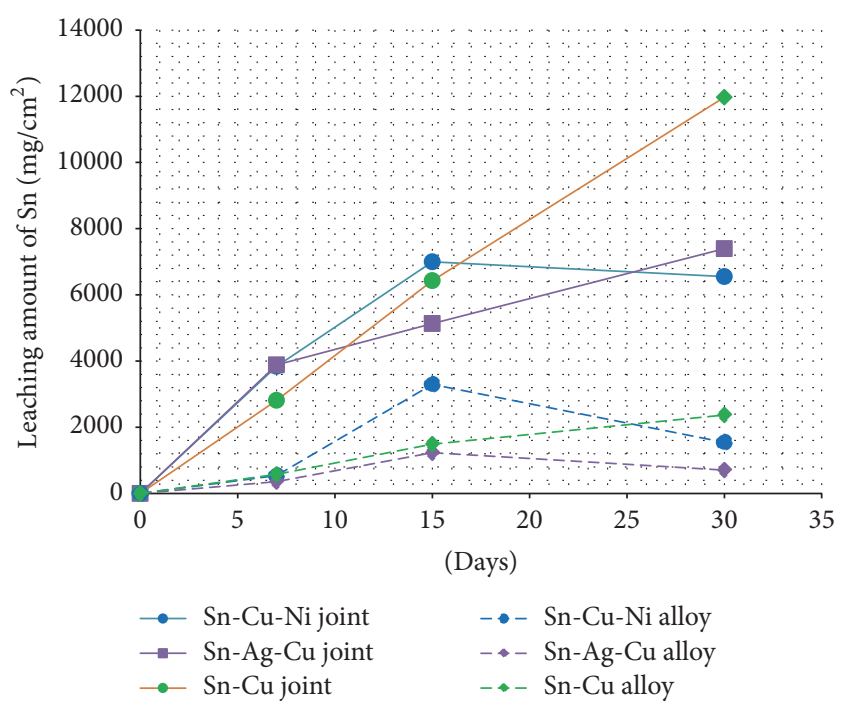

Figure 8: Leaching kinetics of Sn from Sn-Ag-Cu, $\mathrm{Sn}-\mathrm{Cu}-\mathrm{Ni}$, and $\mathrm{Sn}-\mathrm{Cu}$ alloy and their joints in $3.5 \mathrm{wt} . \% \mathrm{NaCl}$ solution.

of Sn for the solder alloys followed by $\mathrm{Sn}$-Cu alloy while Sn$\mathrm{Cu}-\mathrm{Ni}$ had the lowest leaching amount after 30 days. For solder joints, leached $\mathrm{Sn}$ follows the order $\mathrm{Sn}-\mathrm{Cu}>\mathrm{Sn}-\mathrm{Ag}-\mathrm{Cu}$ $>\mathrm{Sn}-\mathrm{Cu}-\mathrm{Ni}$.

Leaching kinetics of $\mathrm{Sn}$ from the metals (Figure 8) show that solder joints gave a higher amount of leached Sn compared to their alloy counterparts. The use of $\mathrm{Cu}$-substrate in the solder joint setup affects the leaching behaviour of Sn. This is because dissimilar metals having different oxidation potentials in contact with each other experience galvanic corrosion $[25,29]$, which does not occur in solder alloys alone. According to Lao et al., [29] the current density of the solder joint is almost twofold higher than its corresponding solder alloy. Thus, the galvanic cell (anode $=\mathrm{Sn}$; cathode $=\mathrm{Cu}$ ) accelerates the leaching amount of $\mathrm{Sn}$ from the joint. 

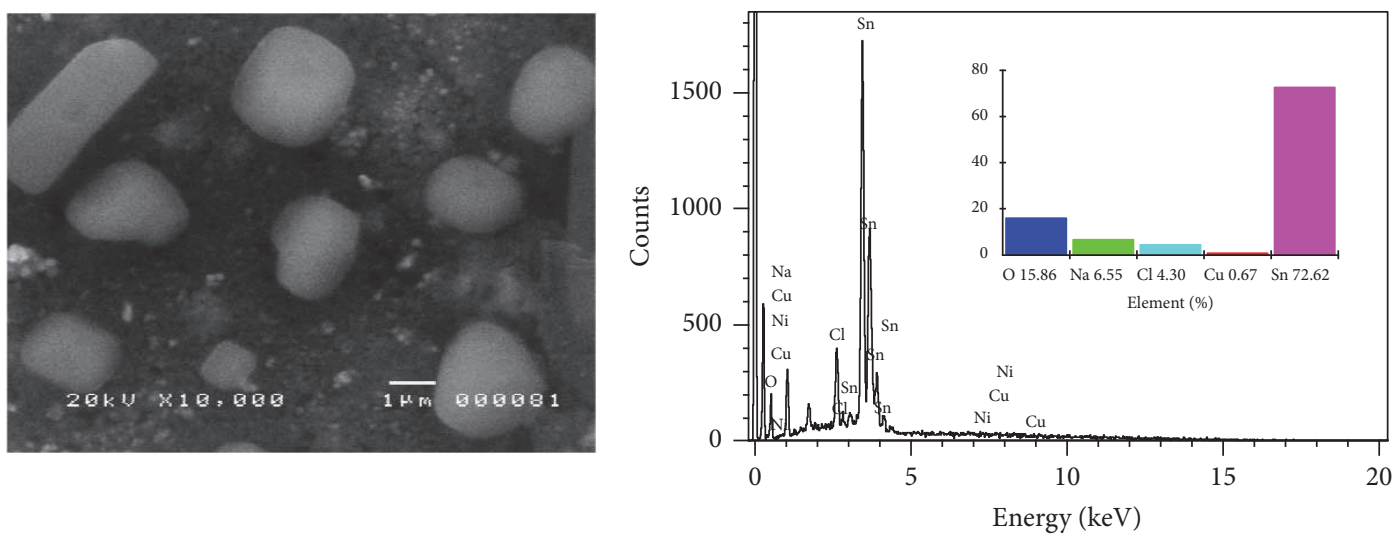

(a)
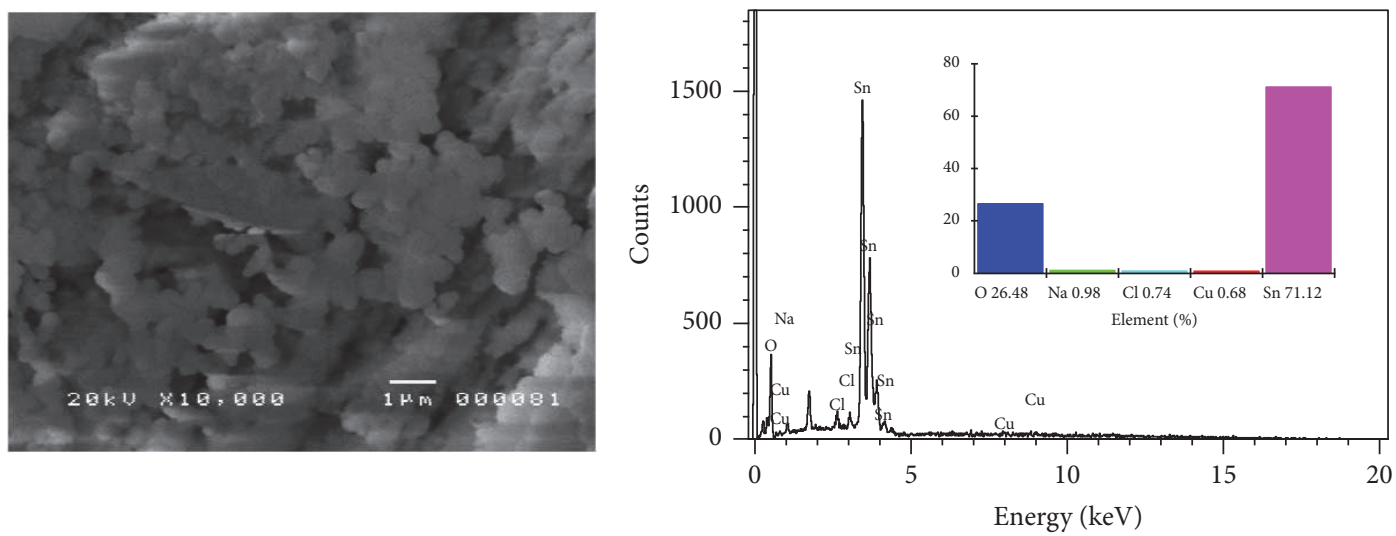

(b)

FIGURE 9: Surface morphology analysis of Sn-Cu-Ni (a) solder alloy and (b) solder joint and their corresponding EDS spectra after 30-day leaching measurements in $3.5 \mathrm{wt} . \% \mathrm{NaCl}$ solution.

The microstructure analysis of $\mathrm{Sn}-\mathrm{Ni}-\mathrm{Cu}$ solder after 30-day immersion in $\mathrm{NaCl}$ solution (Figure 9) showed a more corroded surface for the joint and microstructure is composed of platelet-like materials on the surface. EDS analysis on the surface showed high amounts of Sn and $\mathrm{O}$ suggesting that the corrosion products are composed primarily of oxides of Sn and small amounts of chlorides. This is further confirmed by the detection of XRD patterns specific to $\mathrm{SnO}_{2}$ (Figure 10). Similarly, corresponding peaks for $\mathrm{Sn}(\mathrm{OH})_{2}$ were detected from Yan and Xian [28].

3.2.1. Microstructure of Corrosion Products on Solder Surface. The microstructures of the corrosion surface were monitored as the exposure to the corrosive media increases. Generally, as the alloy (Figure 11) was exposed to the salt solution, the surface changed dramatically from smooth to porous with the formation of plate-like structures attributed to the weakly bonded corrosion products that form on the surface. These compounds, which have been identified in EDS and $\mathrm{XRD}$ as oxides of tin are typical corrosion products. The formation of these compounds is a result of a charge transfer reaction between $\mathrm{Sn}$ metal, salt ion, atmospheric $\mathrm{O}_{2}$, and $\mathrm{H}_{2} \mathrm{O}$ during anodic polarization following the mechanism proposed by Mohran et al. [35]. These corrosion products are weakly held by the bulk metal and can easily chip-off into the solution in agreement with the leaching experiments. The microstructural changes that can be observed for Sn$\mathrm{Cu}-\mathrm{Ni}$ are the noticeable degree of high corrosion product (platelet-like structure) after 7-day exposure compared to Sn$\mathrm{Ag}-\mathrm{Cu}$ and $\mathrm{Sn}-\mathrm{Cu}$. The corrosion products are formed along the cracks, which allow the water to seep-in triggering the corrosion reaction. As the exposure time increases, the entire surface was covered with corrosion products.

For the solder joints, the microstructure changes were likewise monitored (Figure 12). A more dramatic morphology can be observed characterized by branched crystallites, sponge-like structure, networked branches, and platelet-like materials. The formation of these microstructures occurs within 7-day exposure and increases gradually as time increases. This is the consequence of galvanic reaction that occurs since the solder joints are in contact with the $\mathrm{Cu}$ metal as substrate. The galvanic reaction triggers the very fast corrosion process. The EDS analysis of these microstructures reveals $\mathrm{O}$ and $\mathrm{Sn}$-rich surface indicating oxides of $\mathrm{Sn}$ formation, which was further confirmed by XRD as $\mathrm{SnO}_{2}$ (Figure 10).

Generally, the surfaces of the alloys show some corrosion product as evidenced by the plate-like structures. The surfaces 

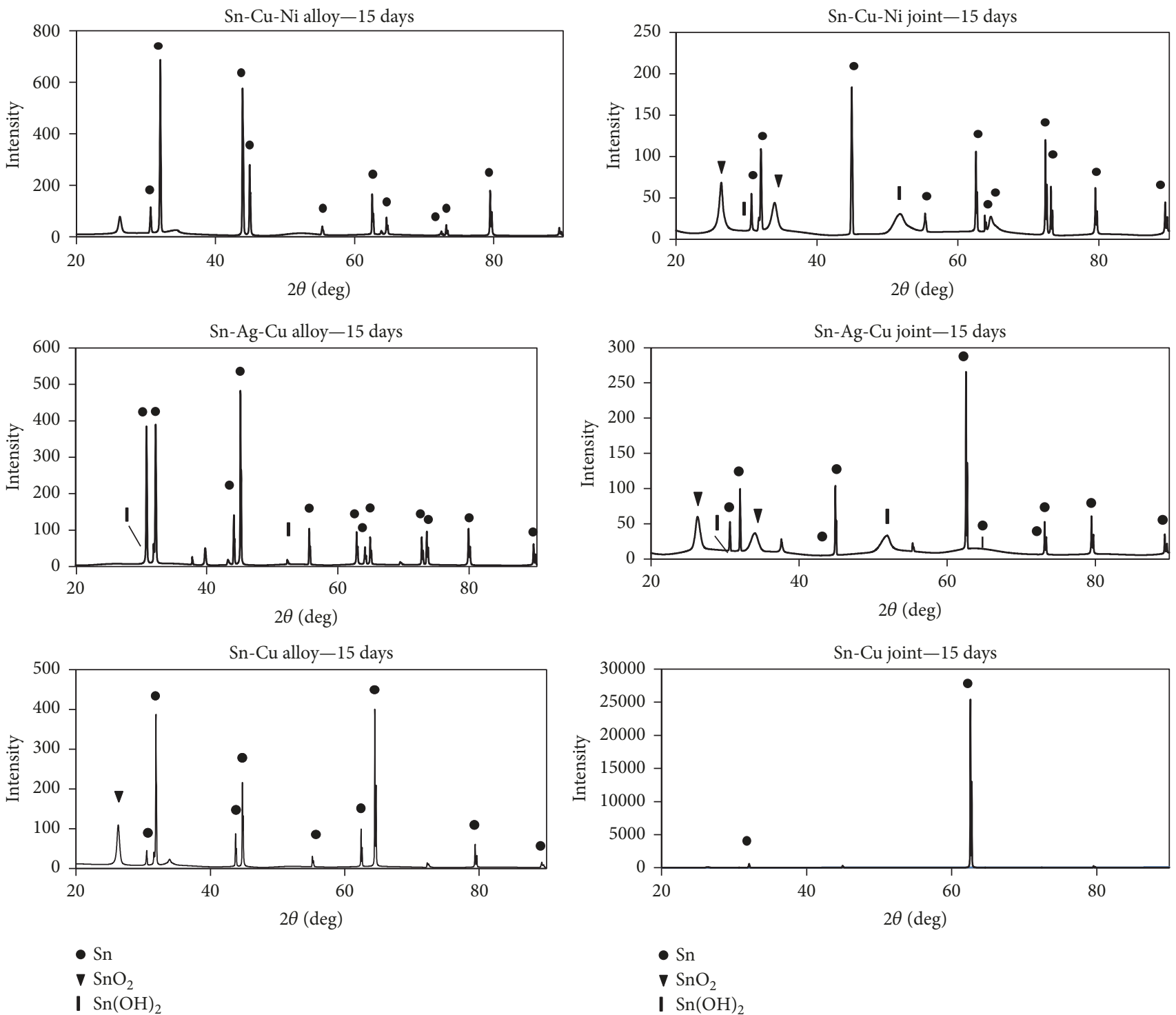

FIGURE 10: XRD patterns of surface product of $\mathrm{Sn}-\mathrm{Ag}-\mathrm{Cu}, \mathrm{Sn}-\mathrm{Cu}-\mathrm{Ni}$, and $\mathrm{Sn}-\mathrm{Cu}$ solder alloy and joint after $15-$ day immersion in 3.5 wt.\% $\mathrm{NaCl}$ solution.

are covered by a small degree of corrosion layer suggesting minimal corrosion on the alloy surface. However, the surface of the joint showed a high degree of corrosion with the entire surface covered with corrosion products forming nanocrystals and sponges. Similar morphology was reported by Lao et al., [29] in the leaching measurement of Sn-0.75Cu solder alloy and joint in simulated soil solutions. The corrosion layer formed on the surface of the alloy forms a protecting film that has a shielding effect on the $\mathrm{Sn}$ ion transport between the solder and the solution. However, in the case of the solder joint, the loosely bound corrosion layer can break-off easily. The corrosion products that made up the surface would no longer protect the substrate resulting in plenty of leaching amounts of Sn coming from the solder joint.

The result of potentiodynamic polarization and leaching tests in $3.5 \mathrm{wt} . \% \mathrm{NaCl}$ solution is conflicting. Results for the Tafel extrapolation show that $\mathrm{Sn}-\mathrm{Cu}-\mathrm{Ni}$ has the highest corrosion rate, while the 30-day immersion of the solder alloy and joint in $\mathrm{NaCl}$ solution showed the lowest amount of leached Sn for all the solders understudied. This was attributed to the rapid analysis in an electrochemical process, where corrosion is forcedly induced on the surface of the metal by applying voltage. A rapid measurement can influence the formation of the passivation film on the surface of the metal. On the other hand, the long exposure time with the corrosive media in leaching experiments allows an actual electrochemical process to occur and measured progressively. In these conditions, the formation of corrosion product is gradual and there is longer timeframe for the stabilization and formation of the passivation film.

These results are significant since, in electronic processes, the solder alloy is not used alone. Rather it is used in contact with other metals mostly $\mathrm{Cu}$ in most electronic substrates. These lead-free solders therefore, once in a corrosive media 


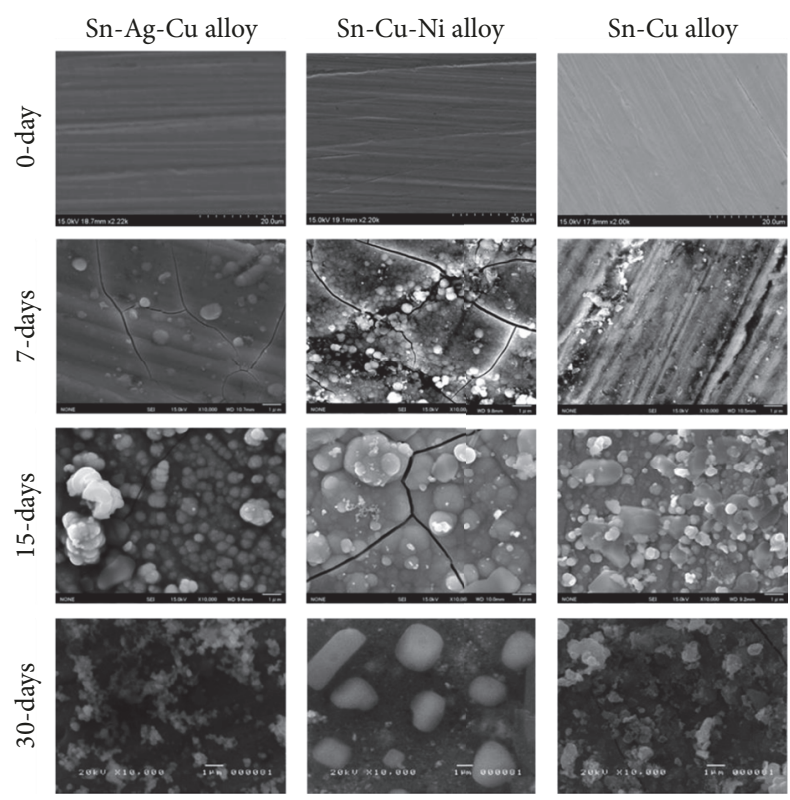

FIGURE 11: SEM image of lead-free solder alloy after 7, 15, and 30 days leaching measurement in $3.5 \mathrm{wt} . \% \mathrm{NaCl}$ solution.
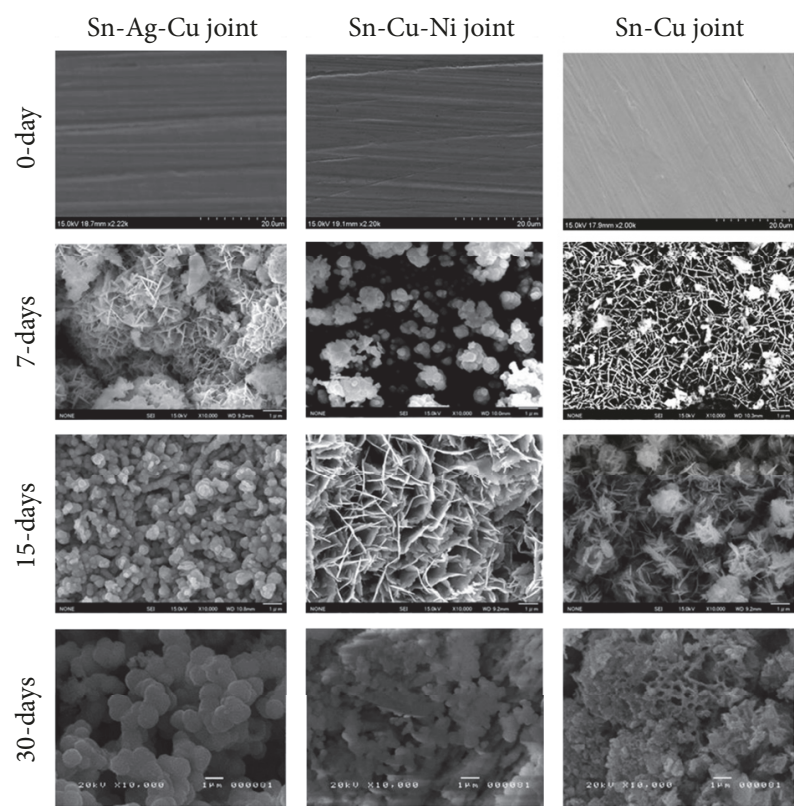

FIGURE 12: SEM image of lead-free solder joint after 7, 15, and 30 days leaching measurement in $3.5 \mathrm{wt} . \% \mathrm{NaCl}$ solution.

such as aqueous $\mathrm{NaCl}$ atmosphere, are prone to corrosion even within 7 days of exposure. The corrosion reaction is triggered by the galvanic reaction that occurs when this happens inside an electronic gadget. The interconnections and electrical connectivity are lost affecting the form, features, and function of the device.

\section{Conclusions}

The corrosion behaviour of $\mathrm{Sn}-\mathrm{Cu}-\mathrm{Ni}$ lead-free solder was described for the first time. In $3.5 \mathrm{wt} . \% \mathrm{NaCl}$ environment, potentiodynamic polarization test revealed that the new Sn$\mathrm{Cu}-\mathrm{Ni}$ solder has higher corrosion rate compared to $\mathrm{Sn}-\mathrm{Cu}$ and $\mathrm{Sn}-\mathrm{Ag}-\mathrm{Cu}$. However, longer exposure of the $\mathrm{Sn}-\mathrm{Cu}-\mathrm{Ni}$ alloy and joint to the corrosive medium for up to 30 days showed the lowest leaching rate of $\mathrm{Sn}$ compared to $\mathrm{Sn}-\mathrm{Cu}$ and $\mathrm{Sn}-\mathrm{Ag}-\mathrm{Cu}$ solders. Generally, alloys have lower leaching rate compared to the corresponding joint due to the galvanic reaction occurring in the joint setup. For chloride-containing solution, the corrosion and leaching behaviour of $\mathrm{Sn}-\mathrm{Ag}-\mathrm{Cu}$ is better compared to $\mathrm{Sn}-\mathrm{Ni}-\mathrm{Cu}$ and $\mathrm{Sn}-\mathrm{Cu}$. Further study is underway in acidic and basic media and will be reported elsewhere.

\section{Conflicts of Interest}

There are no conflicts of interest related to this paper.

\section{Acknowledgments}

This work was supported by the Accelerated Science and Technology Human Resource Development Program (ASTHRDP) of the Department of Science and Technology, Science Education Institute (DOST-SEI). Jan-Ervin C. Guerrero is grateful for the Japan Sakura Science Program.

\section{References}

[1] M. Abtew and G. Selvaduray, "Lead-free solders in microelectronics," Materials Science and Engineering: A Structural Materials: Properties, Microstructure and Processing, vol. 27, no. 5, pp. 95-141, 2000.

[2] S. Tong, Y. von Schirnding, and T. Prapamontol, "Environmental lead exposure: a public health problem of global dimensions," Bulletin of the World Health Organization, 2000, http://www.who.int/bulletin/archives/78(9)1068.pdf.

[3] J. H. Lau and K. Liu, "Global Trends in Lead-free soldering," International Journal of Advanced Packaging Technology, vol. 13, no. 2, pp. 25-28, 2004.

[4] S. Garesan and M. Pecht, Lead Free Electronics, IEEE Press/John Wiley \& Sons. Inc, Hoboken, NJ, USA, 2006.

[5] K. Suganuma, "Advances in lead-free electronics soldering," Current Opinion in Solid State \& Materials Science, vol. 5, no. 1, pp. 55-64, 2001.

[6] N. Chawla, "Thermomechanical behaviour of environmentally benign Pb-free solders," International Materials Reviews, vol. 54, no. 6, pp. 368-384, 2009.

[7] K. Zeng and K. N. Tu, "Six cases of reliability study of Pbfree solder joints in electronic packaging technology," Materials Science and Engineering: Reports, vol. 38, no. 2, pp. 55-106, 2002.

[8] D. K. Mu, S. D. McDonald, J. Read, H. Huang, and K. Nogita, "Critical properties of Cu6Sn5 in electronic devices: recent progress and a review, Current Opinion in Solid State \& Materials Science, vol. 20, no. 2, pp. 55-76, 2016.

[9] H. R. Kotadia, P. D. Howes, and S. H. Mannan, "A review: on the development of low melting temperature $\mathrm{Pb}$-free solders," Microelectronics Reliability, vol. 54, no. 6-7, pp. 1253-1273, 2014.

[10] G. Zeng, S. McDonald, and K. Nogita, "Development of hightemperature solders: review," Microelectronics Reliability, vol. 52, no. 7, pp. 1306-1322, 2012. 
[11] H. Nishikawa, J. Y. Piao, and T. Takemoto, "Effect of Ni addition on interfacial reaction between $\mathrm{Sn}-\mathrm{Cu}$ solder and $\mathrm{Cu}$ base metal," in Joining of Advanced and Specialty Materials VII, Proceedings from Materials Solutions 2004 on Joining of Advanced and Specialty Materials, T. J. Lienert, Ed., vol. 35, pp. 208-211, Columbus, OH, USA, October 2006.

[12] B. L. Silva, N. Cheung, A. Garcia, and J. E. Spinelli, "Evaluation of solder/substrate thermal conductance and wetting angle of Sn-0.7 wt $\% \mathrm{Cu}-(0-0.1 \mathrm{wt} \% \mathrm{Ni})$ solder alloys," Materials Letters, vol. 142, pp. 163-167, 2015.

[13] J.-W. Yoon, B.-I. Noh, B.-K. Kim, C.-C. Shur, and S.-B. Jung, "Wettability and interfacial reactions of $\mathrm{Sn}-\mathrm{Ag}-\mathrm{Cu} / \mathrm{Cu}$ and $\mathrm{Sn}$ Ag-Ni/Cu solder joints," Journal of Alloys and Compounds, vol. 486, no. 1-2, pp. 142-147, 2009.

[14] L. Yang, J. Ge, Y. Zhang, J. Dai, H. Liu, and J. Xiang, "Investigation on the Microstructure, Interfacial IMC Layer, and Mechanical Properties of $\mathrm{Cu} / \mathrm{Sn}-0.7 \mathrm{Cu}-\mathrm{xNi} / \mathrm{Cu}$ Solder Joints," Journal of Electronic Materials, vol. 45, no. 7, pp. 3766-3775, 2016.

[15] H. Nishikawa, J. Y. Piao, and T. Takemoto, "Interfacial reaction between $\mathrm{Sn}-0.7 \mathrm{Cu}(-\mathrm{Ni})$ solder and $\mathrm{Cu}$ substrate," Journal of Electronic Materials, vol. 35, no. 5, pp. 1127-1132, 2006.

[16] S. Farina and C. Morando, "Comparative corrosion behaviour of different Sn-based solder alloys," Journal of Materials Science: Materials in Electronics, vol. 26, no. 1, pp. 464-471, 2014.

[17] K. Pietrzak, M. Grobelny, K. Makowska et al., "Structural aspects of the behavior of lead-free solder in the corrosive solution," Journal of Materials Engineering and Performance, vol. 21, no. 5, pp. 648-654, 2012.

[18] M. Reid and L. F. Garfias-Mesias, "Corrosion of electronics: lead-free initiatives," in Uhlig's Corrosion Handbook, R. W. Revie, Ed., pp. 565-570, John Wiley \& Sons, Inc, Hoboken, NJ, USA, 3rd edition, 2011.

[19] K.-L. Lin and T.-P. Liu, "The electrochemical corrosion behaviour of $\mathrm{Pb}$-free $\mathrm{Al}-\mathrm{Zn}$-Sn solders in $\mathrm{NaCl}$ solution," Materials Chemistry and Physics, vol. 56, no. 2, pp. 171-176, 1998.

[20] D. Li, P. P. Conway, and C. Liu, "Corrosion characterization of tin-lead and lead free solders in $3.5 \mathrm{wt} . \% \mathrm{NaCl}$ solution," Corrosion Science, vol. 50, no. 4, pp. 995-1004, 2008.

[21] W. R. Osório, E. S. Freitas, J. E. Spinelli, and A. Garcia, "Electrochemical behavior of a lead-free $\mathrm{Sn}-\mathrm{Cu}$ solder alloy in $\mathrm{NaCl}$ solution," Corrosion Science, vol. 80, pp. 71-81, 2014.

[22] M. Liu, W. Yang, Y. Ma, C. Tang, H. Tang, and Y. Zhan, “The electrochemical corrosion behavior of $\mathrm{Pb}$-free $\mathrm{Sn}-8.5 \mathrm{Zn}-\mathrm{XCr}$ solders in 3.5 wt.\% NaCl solution," Materials Chemistry and Physics, vol. 168, pp. 27-34, 2015.

[23] A. Kamarul Asri and E. Hamzah, "Corrosion behaviour of leadfree and $\mathrm{Sn}-\mathrm{Pb}$ solders in 3.5wt\% NaCl," Advanced Materials Research, vol. 686, pp. 250-260, 2013.

[24] U. S. Mohanty and K.-L. Lin, "Electrochemical corrosion behaviour of Pb-free Sn-8.5Zn-0.05Al-XGa and Sn-3Ag-0.5Cu alloys in chloride containing aqueous solution," Corrosion Science, vol. 50, no. 9, pp. 2437-2443, 2008.

[25] C. Q. Cheng, F. Yang, J. Zhao, L. H. Wang, and X. G. Li, "Leaching of heavy metal elements in solder alloys," Corrosion Science, vol. 53, no. 5, pp. 1738-1747, 2011.

[26] A. Wierzbicka-Miernik, J. Guspiel, and L. Zabdyr, "Corrosion behavior of lead-free SAC-type solder alloys in liquid media," Archives of Civil and Mechanical Engineering, vol. 15, no. 1, pp. 206-213, 2015.
[27] A. Sharma, S. Das, and K. Das, "Electrochemical corrosion behavior of $\mathrm{CeO}_{2}$ nanoparticle reinforced $\mathrm{Sn}-\mathrm{Ag}$ based lead free nanocomposite solders in 3.5wt.\% NaCl bath," Surface and Coatings Technology, vol. 261, pp. 235-243, 2015.

[28] Z. Yan and A.-P. Xian, "Corrosion of Ga-doped Sn-0.7Cu solder in simulated marine atmosphere," Metallurgical and Materials Transactions A: Physical Metallurgy and Materials Science, vol. 44, no. 3, pp. 1462-1474, 2013.

[29] X.-D. Lao, C.-Q. Cheng, X.-H. Min et al., "Corrosion and leaching behaviors of Sn-based alloy in simulated soil solutions," Transactions of Nonferrous Metals Society of China, vol. 26, no. 2, pp. 581-588, 2016.

[30] F. Arjmand and A. Adriaens, "Influence of $\mathrm{pH}$ and chloride concentration on the corrosion behavior of unalloyed copper in $\mathrm{NaCl}$ solution: a comparative study between the micro and macro scales," Materials, vol. 5, no. 12, pp. 2439-2464, 2012.

[31] B. D. Craig and D. S. Anderson, Eds., Handbook of Corrosion Data, ASM International, Materials Park, OH, USA, 2nd edition, 1995.

[32] T. Ventura, C. M. Gourlay, K. Nogita, T. Nishimura, M. Rappaz, and A. K. Dahle, "The influence of $0-0.1 \mathrm{wt} . \% \mathrm{Ni}$ on the microstructure and fluidity length of $\mathrm{Sn}-0.7 \mathrm{Cu}-\mathrm{xNi}$," Journal of Electronic Materials, vol. 37, no. 1, pp. 32-39, 2008.

[33] P. Harcuba, M. Janeček, and M. Slámová, "The effect of Cu and $\mathrm{Ni}$ on the structure and properties of the IMC formed by the reaction of liquid $\mathrm{Sn}$-Cu based solders with $\mathrm{Cu}$ substrate," in Proceedings of Contributed Papers (WDS '08), part III, pp. 220224, Prague, Czech, June 2008.

[34] M. Mori, K. Miura, T. Sasaki, and T. Ohtsuka, "Corrosion of tin alloys in sulfuric and nitric acids," Corrosion Science, vol. 44, no. 4, pp. 887-898, 2002.

[35] H. S. Mohran, A.-R. El-Sayed, and H. M. Abd El-Lateef, "Anodic behavior of tin, indium, and tin-indium alloys in oxalic acid solution," Journal of Solid State Electrochemistry, vol. 13, no. 8, pp. 1279-1290, 2009. 


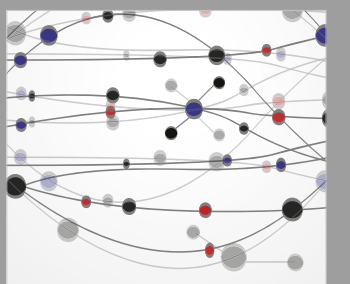

The Scientific World Journal
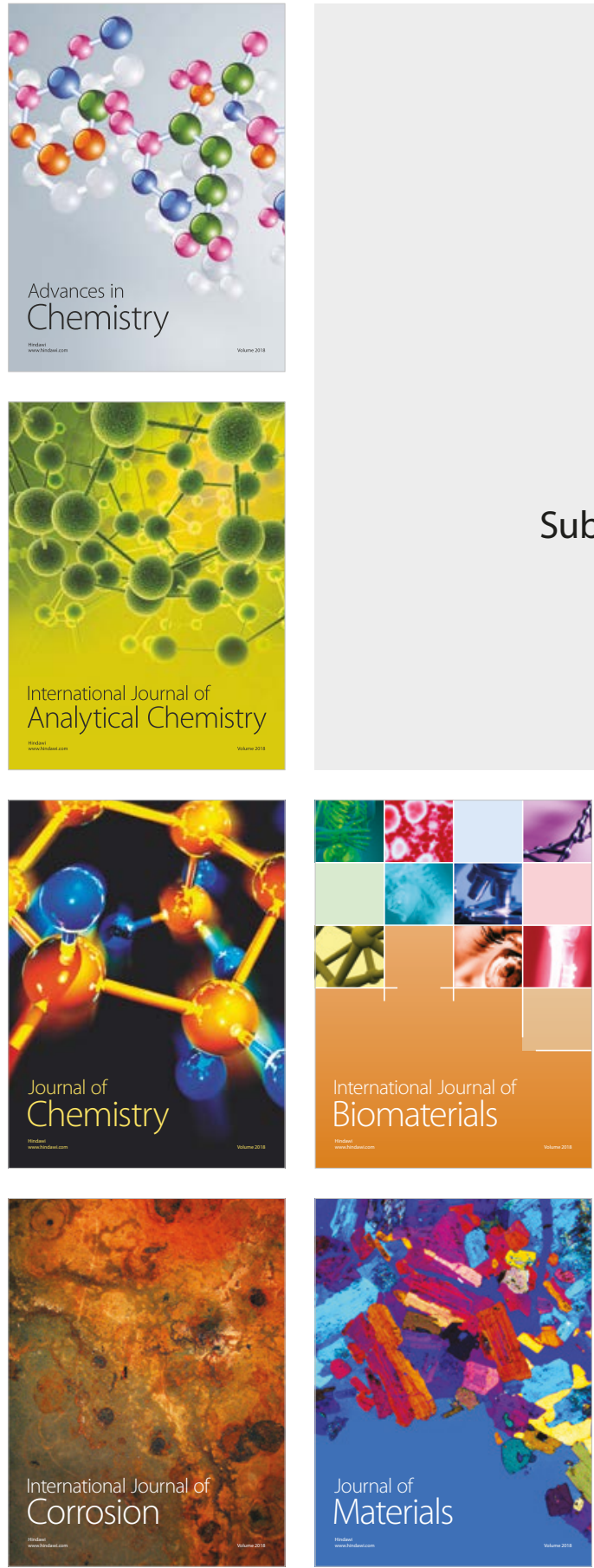

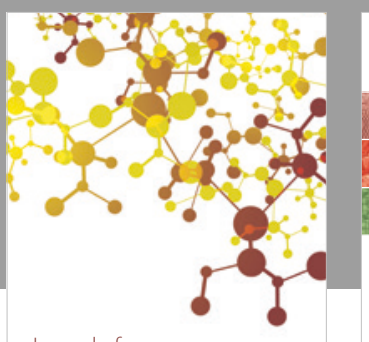

Journal of

Applied Chemistry
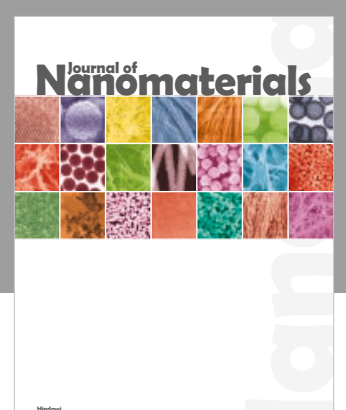

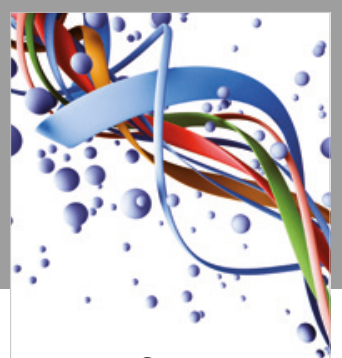

Scientifica

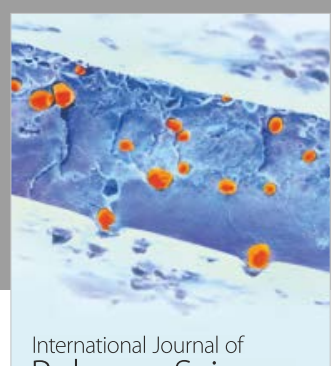

Polymer Science

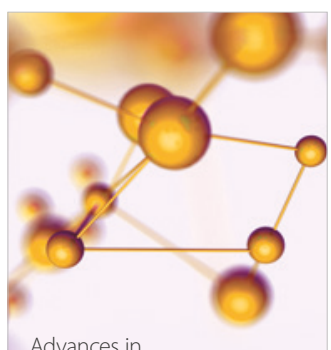

Physical Chemistry
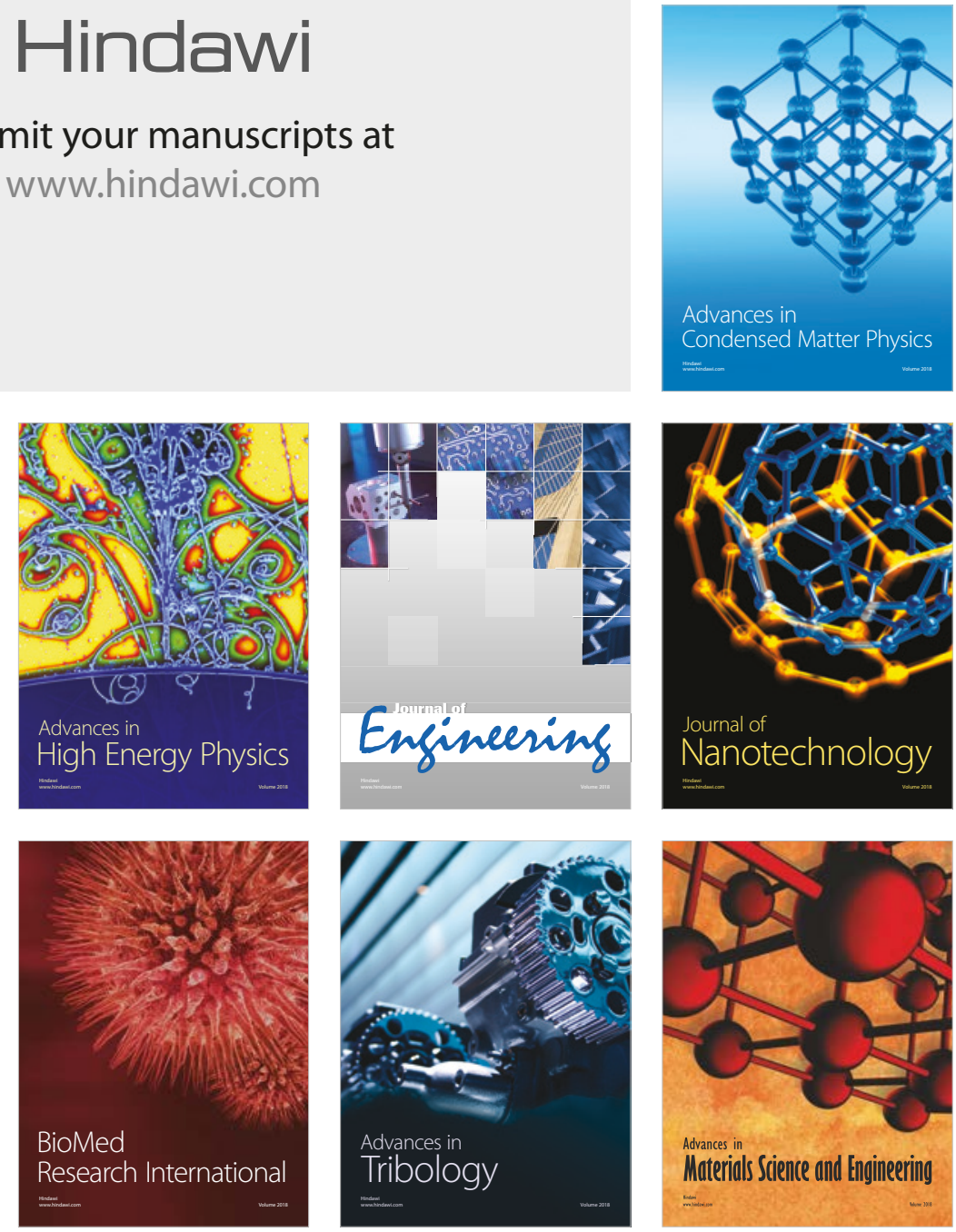